\title{
Gut-Derived Metabolites and Their Role in Immune Dysfunction in Chronic Kidney Disease
}

\author{
Griet Glorieux $^{1, *(\mathbb{D}}$, Tessa Gryp ${ }^{1}\left(\mathbb{D}\right.$ and Alessandra Perna ${ }^{2}(\mathbb{D}$ \\ 1 Nephrology Division, Ghent University Hospital and Ghent University, 9000 Ghent, Belgium; \\ tessa.gryp@ugent.be \\ 2 First Division of Nephrology, Department of Translational Medical Sciences, School of Medicine, \\ University of Campania "Luigi Vanvitelli", 80131 Naples, Italy; alessandra.perna@unicampania.it \\ * Correspondence: griet.glorieux@ugent.be; Tel.: +32-9-3324511
}

Received: 11 March 2020; Accepted: 10 April 2020; Published: 11 April 2020

\begin{abstract}
Several of the uremic toxins, which are difficult to remove by dialysis, originate from the gut bacterial metabolism. This opens opportunities for novel targets trying to decrease circulating levels of these toxins and their pathophysiological effects. The current review focuses on immunomodulatory effects of these toxins both at their side of origin and in the circulation. In the gut end products of the bacterial metabolism such as p-cresol, trimethylamine and $\mathrm{H}_{2} \mathrm{~S}$ affect the intestinal barrier structure and function while in the circulation the related uremic toxins stimulate cells of the immune system. Both conditions contribute to the pro-inflammatory status of patients with chronic kidney disease (CKD). Generation and/or absorption of these toxin precursors could be targeted to decrease plasma levels of their respective uremic toxins and to reduce micro-inflammation in CKD.
\end{abstract}

Keywords: uremic toxins; gut; chronic kidney disease; immune

Key Contribution: Several uremic metabolites and their precursors exert immunomodulatory effects both at their side of origin - the colon-and in the circulation. Both intestinal generation and intestinal transport could be addressed to decrease their levels in the circulation with the aim to reduce micro-inflammation in chronic kidney disease.

\section{Introduction}

Under physiological conditions, cells and tissues are maintained in a homeostatic state while under pathophysiological conditions they experience stress. The latter conditions require adaptation in which the immune system plays an important role. The characteristics of this adaptive response are an intermediate between the basal homeostatic state and an inflammatory response, called low-grade inflammation, switched on in order to restore functionality and homeostasis [1]. Inflammation is mediated by an interaction of multiple components of the innate and adaptive immune system including complement factors, leukocytes and cytokines. Chronic kidney disease (CKD) is a state of chronic, low-grade inflammation which contributes to the accelerated progression of chronic inflammatory disturbances affecting immune balance with increased levels of innate immunity biomarkers, such as C-reactive protein (CRP) and interleukin (IL)-6. Causes and consequences of inflammation and CKD-associated cardiovascular diseases, such as the uremic milieu and infection, have been explored [2]. More recently attention has been paid to the intestine and its microbiota as a potential source of inflammation due to changes in the gut microbial composition and disruption of the intestinal epithelial barrier structure and function in CKD. Levels of uremic toxins and their gut-derived precursors play an important role in the pro-inflammatory response and have been linked to changes in gut microbiota composition [3]. For a long time, the number of identified colon-derived solutes in humans 
remained limited. Recently, metabolome studies made an important contribution to the identification of colon-derived solutes by comparing the urinary metabolome from controls to that of patients with colectomy $[4,5]$. In addition, the comparison of the plasma metabolome from controls and hemodialysis patients revealed colon-derived solutes that accumulate when the kidneys fail. Among the identified colon-derived uremic solutes are the known uremic toxins p-cresyl sulfate (pCS), p-cresyl glucuronide (pCG), indoxyl sulfate (IxS), indole-3-acetic acid (IAA) and trimethylamine N-oxide (TMAO). Levels of all five solutes have previously been shown to be increased in patients with CKD [6-9]. Several biological effects of these compounds have been demonstrated, mainly affecting pathways playing a role in inflammation, metabolic function, cardiovascular disease and fibrosis [10]. More recently, alterations in the sulfur metabolism, prominent in CKD, have been linked to changes in the microbiota composition and function and should be taken into account when evaluating the potential role of uremic toxins and their precursors in immune response and inflammation at their side of origin [11].

\section{The Gut Immune Homeostasis}

A large number of microbiota reside in and on our body, with the largest microbial community located in the gastrointestinal tract [12]. All these microbiota exert metabolic functions, generating metabolites which directly influence our immune and nervous system and several distal organs via the circulation [13]. The human immune system plays an essential role in maintaining homeostasis with resident microbial communities, while resident microbiota per se shape the human immunity [14]. Most knowledge has been gained from studies with germ-free mice and colonized mice revealing the role of microbial colonization in the formation of lymphoid tissues and subsequent immune system development [15].

An important role is reserved for the intestinal epithelium which serves as an immunological guard forming a barrier between the intestinal lumen, containing microbiota and their derivatives and metabolites, and the internal milieu. The gastrointestinal barrier consists of intestinal epithelial cells with, at the apical side, tight junction proteins sealing the cellular layer and preventing translocation from the luminal side towards the blood side. After microbial stimulation, the epithelial cells express patterns of recognition receptors and produce chemotactic factors affecting both myeloid and lymphoid cells. Innate lymphoid cells in the submucosa can be stimulated to produce cytokines, while the dendritic cells in the submucosa often determine whether the response will be pro- or anti-inflammatory. The composition of the intestinal microbiota and their metabolic activity affects the immune response in the submucosa mainly via passive and active transcellular transport of solutes regulated at the apical membrane of the epithelial cells $[13,16]$.

\section{Gut Dysbiosis in CKD}

The gut microbial composition is altered in CKD patients. This was initially observed in culture-based approaches observing increased counts of aerobes and decreased counts of anaerobes in fecal samples [17] and increased counts of aerobes and anaerobes in the small intestines of non-dialyzed and dialyzed patients with end-stage kidney disease (ESKD) compared to controls $[18,19]$. Metagenomic sequencing and qPCR confirmed the altered gut microbial composition in CKD, revealing a difference of 190 microbial operational taxonomic units (OTUs) between ESKD patients and healthy controls [3] and a decline of the short-chain fatty acid (SCFA)-generating bacteria, Bifidobacterium spp. and Lactobacillus spp., and an elevation of Enterobacteriaceae and Escherichia coli with progressive stages of CKD [20]. Recently, Wang et al. demonstrated that alterations in the gut microbiome mediate metabolome changes in patients with ESKD [21]. The alterations in the gut microbial composition, as a potential cause of a change in the gut biochemical milieu in CKD, is further enhanced by several uremia-related factors, while the gut microbiota per se also contribute to CKD by generating the uremic toxin precursor metabolites. This indicates that there is a bidirectional relationship between the gut microbiota and the kidneys, also known as the gut-kidney axis. 
Gut dysbiosis contributes to the disruption of the intestinal barrier integrity causing translocation of bacteria and bacterial components which trigger the intestinal immune system. Under these conditions, intestinal epithelial cells will express pro-inflammatory cytokines, promoting a Th1 and Th17 response by dendritic cells and macrophages and producing increased levels of commensal-specific IgG by B cells. Binding of lipopolysaccharide (LPS) to its receptor complex on macrophages further results in enhanced production of pro-inflammatory cytokines [22]. Circulating endotoxin is a potential cause of inflammation in CKD [23-25]. A dysregulated immune response and chronic production of pro-inflammatory cytokines lead to systemic inflammation, which can further accelerate the progression of CKD and the development of CKD-associated cardiovascular disease.

\section{End Metabolites of Intestinal Bacterial Metabolism}

The bacterial generation of uremic toxin precursors depends on the availability of carbohydrates at the level of the colon. In the presence of an excess of carbohydrates, amino nitrogen is mainly built into the growing bacterial biomass and saccharolytic fermentation prevails, producing SCFAs, keeping the $\mathrm{pH}$ low and suppressing the proteolytic activity $[15,26]$. However, in CKD, characterized by a decreased absorption of amino acids and abnormal intestinal motility in the small intestine and by a prolonged colonic transit $[19,27]$, concentrations of amino acids are higher than expected in the colon. This induces an upstream expansion of proteolytic species and could lead to an increase in the metabolization of aromatic amino acids into precursors of uremic toxins, such as p-cresol, indole and trimethylamine (TMA), and of IAA (Figure 1). In addition, sulfur-containing dietary products and sulfated mucins are metabolized to form hydrogen sulfide $\left(\mathrm{H}_{2} \mathrm{~S}\right)$ [11]. Currently, few reports on intestinal levels of these metabolites are available [28], while the existing data diverge [29,30]. In the following paragraphs, the potential biological effects of these metabolites at their side of origin are described, focusing on cells of the immune system and immune response, as summarized in Table 1.

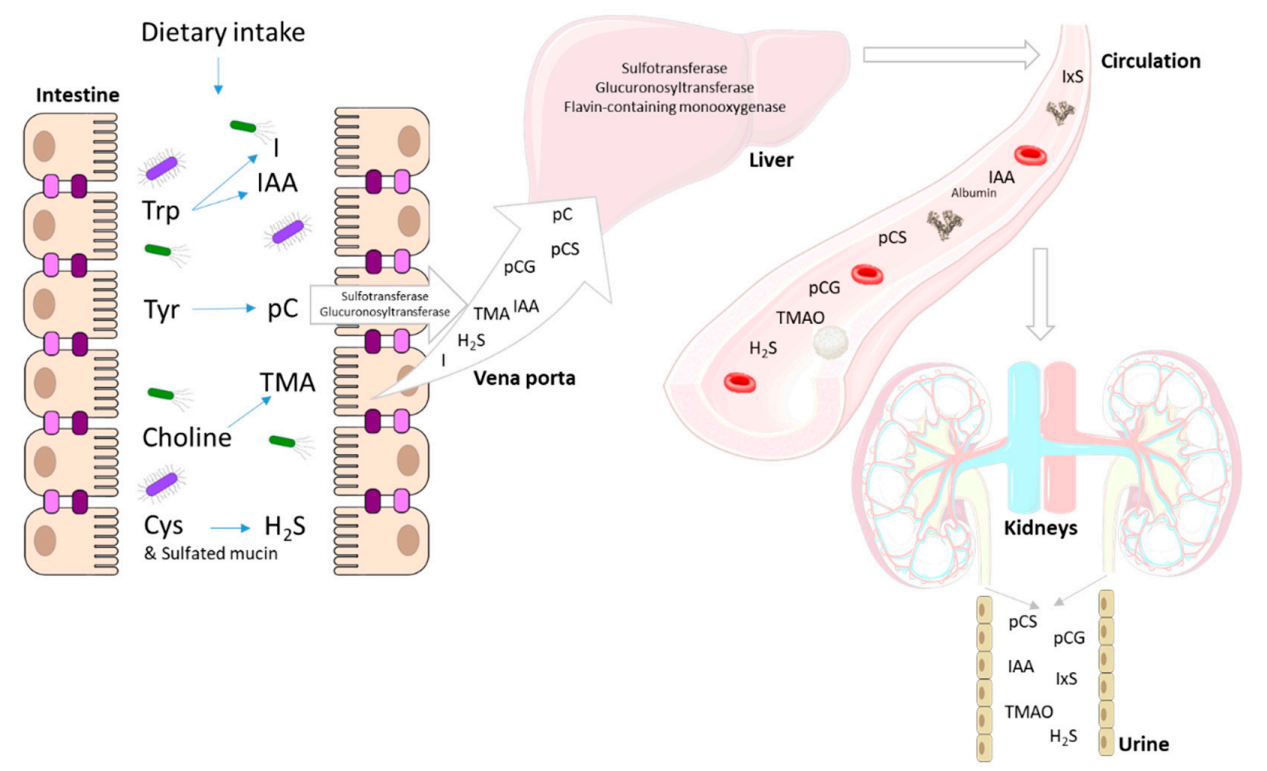

Figure 1. End products of the intestinal bacterial metabolism (I, IAA, pC, TMA, $\mathrm{H}_{2} \mathrm{~S}$ ) are transported as such or after detoxification (sulfatation and glucuronidation) towards the liver via the portal vein where the remaining $\mathrm{pC}$ and I are conjugated and TMA is oxygenated. The end products of the bacterial and human metabolism are taken up into the circulation (IxS, IAA, pCS, pCG, TMAO, $\mathrm{H}_{2} \mathrm{~S}$ ) where some bind to albumin (IxS, IAA, pCS and to a lesser extend $\mathrm{pCG}$ ). $\mathrm{H}_{2} \mathrm{~S}$ is also generated by different tissues throughout the body. Finally, these compounds are excreted into the urine. Trp: tryptophan; Tyr: tyrosine; Cys: cysteine; I: indole; IAA: indole-3-acetic acid; pC: p-cresol; TMA: trimethylamine; TMAO: trimethylamine N-oxide; pCS: p-cresyl sulfate; pCG: p-cresyl glucuronide; IxS: indoxyl sulfate. 


\section{1. $p$-Cresol}

$\mathrm{p}$-Cresol $(108.14 \mathrm{~g} / \mathrm{mol})$ is an end product of the bacterial metabolization of the aromatic amino acid tyrosine $(181.19 \mathrm{~g} / \mathrm{mol})$ in the colon. Kawakami et al. reported that fasting in rats enhances the production of $p$-cresol due to an increased concentration of endogenous protein in the caecum [31]. At the side of the colonic epithelial cells, in HT29 Glc $(-/+)$ cells, p-cresol has been shown to significantly increase lactate dehydrogenase leakage and decrease adenosine triphosphate (ATP) content, while in Caco-2 cell monolayers, p-cresol significantly decreases the transepithelial electrical resistance and increases the paracellular transport of fluorescent isothiocyanate (FITC)-dextran [32]. In addition, the genotoxicity of $\mathrm{p}$-cresol was suggested by the induction of DNA damage, affecting cell cycle kinetics in HT29 and Caco-2 cells [33]. These studies point to the local contribution of p-cresol to the disruption of the intestinal barrier function, which will indirectly affect the host immune response. Furthermore, incubation of Lactobacillus casei Shirota-stimulated J774.1 cells, a murine macrophage-like cell line, in the presence of p-cresol, inhibited IL-12 p40 production in a dose-dependent manner [34]. Previously, p-cresol was also shown to suppress monocyte and granulocyte respiratory burst activity [35]. These data suggest that at the side of the intestine, $\mathrm{p}$-cresol could exert deleterious effects on the host defense system per se.

\subsection{Indole and Indole-3-Acetic Acid}

Both indole $(117.15 \mathrm{~g} / \mathrm{mol})$ and indole-3-acetic acid $(175.18 \mathrm{~g} / \mathrm{mol})$ are metabolites from the bacterial tryptophan $(204.22 \mathrm{~g} / \mathrm{mol})$ metabolism. These metabolites are bioactive and can affect the intestinal barrier function and immune cells via the pregnane $X$ receptor (PXR) and the aryl hydrocarbon receptor (AhR), both playing a role in the expression of the mucin 2 gene, which is essential for an intact epithelial barrier [36,37]. Indole functions as a signaling molecule in the gut homeostasis where it can regulate bacterial motility, biofilm formation, antibiotic resistance, and secretion of virulence factors affecting host cell invasion by non-indole-producing species, such as Salmonella enterica and Pseudomonas aeruginosa and even the yeast Candida albicans [38]. Indole has also been recognized as a beneficial signal molecule in intestinal epithelial cells. It ameliorates intestinal inflammation as demonstrated by the decreased TNF- $\alpha$-mediated activation of nuclear factor (NF)- $\mathrm{kB}$, the decreased expression of the pro-inflammatory chemokine IL-8, and the decreased attachment of pathogenic E. coli to the human enterocyte cell line, HCT-8 cells, as well as the increased expression of the anti-inflammatory cytokine IL-10 [39]. Indole also increased the expression of genes involved in strengthening the mucosal barrier and mucin production, which were consistent with an increase in the transepithelial resistance of HCT-8 cells [39].

Data on the local effect of IAA in the intestine are limited. Hendrikx et al. reported that restoration of intestinal levels of IAA protected mice from ethanol-induced steatohepatitis by inducing intestinal expression of IL-22 and antimicrobial C-type lectin regenerating islet-derived 3 gamma (REG3G), preventing translocation of bacteria to the liver [40].

In contrast to p-cresol, both indole and IAA exert beneficial effects in the gut by regulating gut homeostasis and by strengthening the mucosal barrier and mucin production.

\subsection{Trimethylamine}

The fishy, odorous trimethylamine $(59.11 \mathrm{~g} / \mathrm{mol})$ is produced from the bacterial metabolization of dietary products such as phosphatidylcholine and carnitine, found in fish, seafood, eggs, cheese and red meat. TMA is rapidly absorbed through the gut wall and transported to the liver, where it is converted into nonodorous TMAO by the enzyme flavin-containing monooxygenase- 3 . Although no local intestinal toxic effects could be retrieved from literature, TMA was suggested to affect other barrier functions such as in the respiratory tract and the skin [41,42]. 


\subsection{Sulfur Compounds}

Among the sulfur compounds present in the gut, $\mathrm{H}_{2} \mathrm{~S}$ is currently one of the most extensively studied. $\mathrm{H}_{2} \mathrm{~S}(34.08 \mathrm{~g} / \mathrm{mol})$ is a gas produced by the body, with many biological functions among which anti-inflammatory and anti-oxidant properties. However, it must be kept in mind that $\mathrm{H}_{2} \mathrm{~S}$ is also a lethal toxin when present at high concentrations, inhibiting complex IV in the mitochondrial respiratory electron transfer chain.

The various forms in which $\mathrm{H}_{2} \mathrm{~S}$ is present are: free $\mathrm{H}_{2} \mathrm{~S}$ (gaseous $\mathrm{H}_{2} \mathrm{~S}$, along with the HS-hydrosulfide anion, and $S^{2-}$ sulfide anion), the acid-labile sulfur (iron-sulfur clusters and persulfides), and the bound sulfane sulfur (thiol sulfides, polysulfides, sulfate/sulfite, and bound elemental sulfur). It is produced both enzymatically and nonenzymatically. Three enzymes are involved: cystathionine $\beta$-synthase (CBS, brain), cystathionine $\gamma$-lyase (CSE, vascular tissues, liver, kidney), and 3-mercaptopyruvate sulfurtransferase (MST, kidney). CBS and CSE belong to the transsulfuration pathway, which is mainly devoted to (1) the endogenous generation of cysteine, (2) homocysteine detoxification, and (3) $\mathrm{H}_{2} \mathrm{~S}$ generation (and concomitant lanthionine production). In red blood cells (and other tissues, such as spleen, heart, lung, muscle, bone marrow) it is likely most often produced nonenzymatically, utilizing cysteine [43]. $\mathrm{H}_{2} \mathrm{~S}$ can signal through four mechanisms [44]: (1) reduction and/or direct binding of metalloprotein heme centers; (2) antioxidant action through reactive oxygen species (ROS)/reactive nitrogen species scavenging; (3) post-translational modification of proteins by addition of a thiol (-SH) group onto reactive cysteine residues, so-called persulfidation (or S-sulfhydration), and formation of polysulfides [45,46]; (4) a postulated redox-linked metabolic reprogramming mechanism through sulfide quinone oxidoreductase in mitochondria [47].

Even considering the difficulties in accurately measuring $\mathrm{H}_{2} \mathrm{~S}$ and the various species in which it is present [48], its concentration in tissues and blood is usually in the low micromolar range; however, in the luminal content of the large intestine the total sulfide concentration is about 0.2-2.4 $\mathrm{mM}$ [49]. The sources of $\mathrm{H}_{2} \mathrm{~S}$ in the gut are the Sulfate Reducing Bacteria (SRB), gut fermentative bacteria, and colonic tissues. About $50 \%$ of $\mathrm{H}_{2} \mathrm{~S}$ originates from the bacterial metabolization of sulfur-containing dietary products and sulfated mucins present in the outer mucus layer of the colon [50]. Colon epithelial cells are adapted to the high environmental $\mathrm{H}_{2} \mathrm{~S}$ exposure; in fact, these cells possess an efficient mitochondrial $\mathrm{H}_{2} \mathrm{~S}$ oxidation pathway, dedicated to its disposal. Intestinal epithelial cells express enzyme systems that efficiently degrade sulfide into thiosulfate and sulfate, which are absorbed and finally excreted in the urine [51,52].

To date, it is not entirely clear if gut $\mathrm{H}_{2} \mathrm{~S}$ is a mediator of a productive mutualistic relationship at the host-microbial interface or a simple metabolic byproduct of enzymatic reactions, but this is less likely [42]. It is known that $\mathrm{H}_{2} \mathrm{~S}$ is useful to the local gut bacteria because it increases bacterial resistance to antibiotics [53], it acts as a protective mechanism against ROS [54], and it provides bacterial resistance towards elimination by the host immune system [55]. However, the physiologic and regulatory roles of $\mathrm{H}_{2} \mathrm{~S}$ in a healthy and a diseased gut are still not well defined. Mercaptides, such as $\mathrm{H}_{2} \mathrm{~S}$, help to maintain anaerobic conditions in the colonic lumen. There is even evidence that the recycling of $\mathrm{H}_{2} \mathrm{~S}$ by a "thiosulfate shunt" integrates the enzymatic activities of both the intestinal epithelial cells and intestinal microbiota. On the other hand, high $\mathrm{H}_{2} \mathrm{~S}$ levels have been shown to inhibit butyrate oxidation, an important energy source of the colonic epithelial cells [56]. In the end, $\mathrm{H}_{2} \mathrm{~S}$ has beneficial effects on the local intestinal microbiota, but it could negatively affect the intestinal barrier function because it has been suggested that $\mathrm{H}_{2} \mathrm{~S}$ plays a potential role in the etiology of bowel disorders such as inflammatory bowel diseases. In addition, gut-derived $\mathrm{H}_{2} \mathrm{~S}$ is able to exert hypotensive effects [49].

It has been shown in a germ-free mice model that free $\mathrm{H}_{2} \mathrm{~S}$ and bound sulfane sulfur are significantly reduced in plasma, while acid-labile sulfide levels remain normal [57]. In the same paper, CSE activity is also lower in several tissues, such as the aorta, the brain, and kidneys. $\mathrm{H}_{2} \mathrm{~S}$ is also significantly lower in plasma from CKD and hemodialysis patients compared to controls, while the metabolic related compounds cystathione, homolanthionine and lanthionine are significantly increased [58]. In this respect, lanthionine, a byproduct of the transsulfuration pathway found to be quite high in 
the plasma of CKD patients, is able to exert several toxic effects [59-62]. Lanthionine is also an end product of bacterial metabolism. Very little is currently known about the levels of these compounds in the intestinal environment of CKD patients and whether differences in the gut microbiota composition present in $\mathrm{CKD}$ affect $\mathrm{H}_{2} \mathrm{~S}$ levels or its effects.

\section{Immunomodulatory Effects of Uremic Toxins from Colonic Origin}

\section{1. $p$-Cresyl Sulfate}

Detoxification of p-cresol occurs in the mucosa of the colon [63] and in the liver [64], where it is sulfated into pCS $(188.2 \mathrm{~g} / \mathrm{mol})$ and a small fraction is glucuronidated into pCG $(283.3 \mathrm{~g} / \mathrm{mol})[65,66]$. When entering the circulation these solutes bind to plasma albumin in a reversible manner [67]. pCS was suggested to cause immune dysfunction and increase the risk of infectious diseases in CKD patients. Schepers et al. demonstrated for the first time an in vitro biological effect of pCS at uremic concentrations, revealing an increase in the percentage of leukocytes displaying oxidative burst activity at baseline and an inhibition of the leukocyte burst activity after stimulation [68]. A synergistic activating effect was observed when the glucuronide conjugate of p-cresol, pCG, was added [69]. This was confirmed in an in vivo microscopic rat model where superfusion of the peritoneal membrane with pCS caused a rapid increase in the number of rolling leukocytes while the combination of both pCS and pCG caused impaired blood flow and vascular leakage but did not further enhance leukocyte rolling over pCS alone [70]. Activation of leukocytes per se and increased crosstalk between leukocytes and the vascular endothelial cells in the presence of pCS may contribute to the pro-inflammatory condition which is characteristic for CKD patients. In addition, Han and coworkers demonstrated that pCS promotes plaque growth and instability in ApoE KO mice by enhancing leukocyte-endothelium interaction [71].

Although the total uremic milieu was shown to suppress monocytic CYP27B1 expression, an enzyme regulating local production of 1,25-dihydroxyvitamin D3 in monocytes playing a role in the immunomodulatory effects of vitamin D, no specific contribution of pCS could be demonstrated [72]. Shiba et al. demonstrated that mice fed a tyrosine-rich diet causing pCS accumulation in their blood revealed a suppressed Th1-type cellular immune response demonstrated by the suppressed production of interferon (IFN)-gamma and the decreased percentage of IFN-gamma-producing Th1 cells in the presence of pCS [73]. Later on, the same group also demonstrated that pCS suppresses LPS-induced anti-bacterial immune responses in murine macrophages [74] and decreases peripheral B cells by inhibiting proliferation of CD43(+) B-cell progenitors in vitro [75]. pCS was shown to induce macrophage activation demonstrated by increased oxidative burst activity and phagocytosis but interfered in antigen processing, leading to a failure in adaptive immune response in CKD [76]. Levels of terminally differentiated CD8+ T cells also positively correlated with the level of pCS pointing to a premature aging phenotype of the immune system in patients with ESKD [77]. More recently, Borges Bonan and coworkers demonstrated that a combination of sulfated uremic toxins, among which pCS and IxS contribute to the increasing proportion of intermediate (CD14++CD16+) pro-inflammatory monocytes in CKD patients [78].

\subsection{Indoxyl Sulfate}

The intestinally generated indole is further metabolized in the liver to indoxyl sulfate $(213.21 \mathrm{~g} / \mathrm{mol})$. Among other uremic toxins, IxS is a ligand of the AhR. The AhR regulates both innate and adaptive immune responses and is expressed in dendritic cells (DCs). The AhR inhibits the development of plasmacytoid DCs from bone marrow precursors induced by FMS-like tyrosine kinase-3 ligand (Flt3L), probably via inhibition of signal transducer and activator of transcription-3 (STAT3) expression [79]. The study by Ghimire et al. suggested an anti-inflammatory and tolerizing effect of IxS on human DCs [80]. However, in monocytes, the response to IxS through the AhR increases levels of TNF- $\alpha$ and upon stimulation with TNF- $\alpha$, human vascular endothelial cells express CX3CL1, a chemokine ligand of CX3CR1 [81]. In addition, IxS induces monocytic ROS production in an NADPH oxidase-dependent 
manner [82]. The IxS-induced TNF- $\alpha$ production in macrophages is regulated through a mechanism involving the interaction of $\mathrm{AhR}, \mathrm{NF}-\mathrm{kB}$, and the suppression of cytokine signaling [83]. IxS also increases LPS-induced NF- $\mathrm{kB}$ nuclear translocation, ROS release and altered calcium concentrations in J774A.1 macrophages, mainly because of mitochondrial calcium overloading [84]. In RAW 264.7 culture, NF- $\kappa$ B mRNA expression was stimulated by IxS, while nuclear factor erythroid 2-related factor 2 (Nrf2) was downregulated, triggering inflammation and oxidative stress [85]. Finally, IxS enhances leukocyte adhesion to the endothelial cells in vitro by the ROS/p38 MAPK pathway and the ROS/JNK/NF- $\kappa$ B pathway [82,86]. These effects indicate that IxS-mediated immune dysfunction may cause vascular endothelial cell damage in CKD patients.

\subsection{Indole-3-Acetic Acid}

In humans, indole acetic-3-acid directly originates from tryptophan metabolism by intestinal bacteria and from tryptophan in various tissues. The toxic effect of IAA in neutrophils is associated with cell peroxidase activity [87] and these processes have been involved in the activation of the glucose and glutamine metabolism [88]. There is a direct correlation between the cytotoxic effect of IAA and the peroxidase activity of the cells, with neutrophils presenting a higher peroxidase activity than inflammatory macrophages, whereas in resident macrophages and in lymphocytes this enzyme activity is very low [89]. IAA leads to marked structural changes and death of cultured neutrophils [87,89], whereas the toxic effects of IAA on lymphocytes are only observed when exogenous peroxidase is added to the culture medium or when they are co-cultivated with neutrophils [90]. In addition, IAA was shown to enhance glucose and glutamine metabolism in neutrophils and thioglycollate-elicited macrophages. IAA caused a marked increase in oxygen consumption by neutrophils, which was more pronounced in the presence of glutamine as compared to glucose. The stimulation of oxygen consumption leads to a reduction in the NADH/NAD+ ratio that activates the flux of substrates through the Krebs cycle [88]. Subcutaneous IAA administration in rats promotes an increased neutrophil phagocytic capacity without a pro-oxidant effect [91]. Finally, IAA was shown to damage DNA in human neutrophils. This genotoxicity negatively correlates with the antioxidant activities, as measured by the 2,2-diphenyl-1-picrylhydrazyl (DPPH) assay [92].

\subsection{Trimethylamine $\mathrm{N}$-Oxide}

Flavin-containing monooxygenase enzymes encoded by the FMO gene family are involved in TMAO $(75.11 \mathrm{~g} / \mathrm{mol})$ production from TMA in the liver, kidney and other tissues [93]. TMAO up-regulates vascular cell adhesion molecule-1 (VCAM-1) expression, promotes monocyte adherence and activates protein kinase $\mathrm{C}(\mathrm{PKC})$ and $\mathrm{p}-\mathrm{NF}-\mathrm{kB}$. Interestingly, a PKC inhibitor was able to diminish the TMAO-stimulated VCAM-1 expression and monocyte adherence. Pharmacological inhibition revealed that endothelial cell adhesion of leukocytes was necessary for TMAO to induce inflammatory gene expression [94]. This points to the fact that TMAO promotes an early pathological process of atherosclerosis [95]. Haghikia et al. suggested that TMAO-related increase of pro-inflammatory monocytes may add to the elevated cardiovascular risk of patients with increased TMAO levels [96].

\subsection{Sulfur Compounds}

The effect of $\mathrm{H}_{2} \mathrm{~S}$ on immune function has been investigated in different models, at different concentrations, with diverged results. $\mathrm{H}_{2} \mathrm{~S}$ is generated at site of inflammation and can influence the ability of neutrophils to cause tissue injury. The $\mathrm{H}_{2} \mathrm{~S}$ donor, sodium hydrosulfide, was shown to suppress leukocyte adherence to the vascular endothelium and to reduce leukocyte infiltration. Suppression of endogenous $\mathrm{H}_{2} \mathrm{~S}$ synthesis through blockade of CSE abolished this anti-inflammatory effect [97]. Zanardo et al. demonstrated in an intra-vital microscopic rat model that $\mathrm{H}_{2} \mathrm{~S}$ donors inhibited aspirin-induced leukocyte adherence in mesenteric venules, likely via the activation of ATP-sensitive $\mathrm{K}+$ channels [98]. Inhibition of endogenous $\mathrm{H}_{2} \mathrm{~S}$ synthesis elicited leukocyte adherence and leukocyte infiltration was also suppressed by $\mathrm{H}_{2} \mathrm{~S}$ donors and exacerbated by inhibition of 
endogenous $\mathrm{H}_{2} \mathrm{~S}$ synthesis [98]. These results suggest that endogenous $\mathrm{H}_{2} \mathrm{~S}$ is an important mediator of acute inflammation, acting at the leukocyte-endothelium interface. Key discoveries concerning $\mathrm{H}_{2} \mathrm{~S}$ were recently reviewed by Szabo [99].

Table 1. (Patho)physiological effects of intestinally generated uremic toxins and their precursors at their side of origin.

\begin{tabular}{|c|c|c|c|}
\hline Metabolites & Side of Origin & (Patho) Physiological Effects & Ref. \\
\hline \multicolumn{4}{|c|}{ Metabolites Generated by Gut Bacteria } \\
\hline p-Cresol & Colon & $\begin{array}{c}\text { Intestinal epithelial cells: } \\
\uparrow \text { LDH leakage } \\
\downarrow \text { ATP content } \\
\downarrow \text { TEER } \\
\uparrow \text { Paracellular transport } \\
\text { Genotoxicity } \\
\text { Leukocytes/Macrophages: } \\
\downarrow \text { IL-12 p40 production } \\
\downarrow \text { Respiratory burst activity }\end{array}$ & $\begin{array}{l}{[32]} \\
{[33]} \\
{[34]} \\
{[35]}\end{array}$ \\
\hline Indole & Colon & $\begin{array}{c}\text { Intestinal epithelial cells: } \\
\uparrow \text { Mucin2 expression } \\
\text { Regulation of gut homeostasis } \\
\downarrow \mathrm{TNF}-\alpha \text { mediated NF- } \mathrm{KB} \text { activation } \\
\downarrow \mathrm{IL}-8 \text { expression } \\
\uparrow \mathrm{IL}-10 \text { expression } \\
\uparrow \text { TER }\end{array}$ & $\begin{array}{c}{[36,37]} \\
{[38]} \\
{[39]}\end{array}$ \\
\hline Indole-3-acetic acid & Colon & $\begin{array}{c}\text { Intestinal epithelial cells: } \\
\uparrow \text { IL-22 expression } \\
\uparrow \text { Antimicrobial C-type lectin REG3G }\end{array}$ & [40] \\
\hline Trimethylamine & Colon & ND & \\
\hline $\mathrm{H}_{2} \mathrm{~S}$ & Colon & $\begin{array}{c}\text { Intestinal bacteria: } \\
\uparrow \text { Antibiotic resistance } \\
\text { Protection against ROS } \\
\text { Protection against immune cells } \\
\text { Maintenance of anaerobic conditions } \\
\downarrow \text { Butyrate oxidation }\end{array}$ & $\begin{array}{l}{[53]} \\
{[54]} \\
{[55]} \\
{[56]}\end{array}$ \\
\hline \multicolumn{4}{|c|}{ Circulating Uremic Toxins } \\
\hline p-Cresyl sulfate & $\begin{array}{l}\text { Intestinal } \\
\text { epithelial cells } \\
\text { and liver }\end{array}$ & $\begin{array}{c}\text { Leukocytes: } \\
\uparrow \text { Baseline ROS and } \downarrow \text { ROS after stimulation } \\
\uparrow \text { Rolling } \\
\uparrow \text { Plaque growth and instability } \\
\downarrow \text { IFN } \gamma \text {-producing Th1 cells } \\
\downarrow \text { Anti-bacterial immune response } \\
\downarrow \text { Proliferation of CD43(+) B cell progenitors } \\
\uparrow \text { Macrophage activation } \\
\downarrow \text { Antigen processing } \\
\text { Premature aging of immune cells }\end{array}$ & $\begin{array}{l}{[68]} \\
{[70]} \\
{[71]} \\
{[73]} \\
{[74]} \\
{[75]} \\
{[76]} \\
{[77]}\end{array}$ \\
\hline $\begin{array}{c}\text { p-Cresyl } \\
\text { glucuronide }\end{array}$ & $\begin{array}{l}\text { Intestinal } \\
\text { epithelial cells } \\
\text { and liver }\end{array}$ & $\begin{array}{c}\text { Leukocytes: } \\
\text { Synergistic to pCS: } \uparrow \text { ROS, impaired blood } \\
\text { flow; vascular leakage }\end{array}$ & $\begin{array}{l}\text { [69] } \\
\text { [70] }\end{array}$ \\
\hline Indoxyl sulfate & Liver & $\begin{array}{c}\text { Anti-inflammatory and tolerizing effect on } \\
\text { DCs } \\
\text { Monocytes: } \\
\uparrow T N F-\alpha \rightarrow \text { HUVEC CX3CL1 } \\
\uparrow \text { ROS } \\
\uparrow \text { Leukocyte-endothelial cell adhesion } \\
\text { Macrophages: } \\
\uparrow T N F-\alpha \\
\uparrow N F-\kappa B, \text { ROS, mitochondrial } \mathrm{Ca}^{2+} \\
\text { overload } \\
\downarrow N r f 2\end{array}$ & $\begin{array}{c}{[81]} \\
{[82]} \\
{[82,86]} \\
{[83]} \\
{[84]} \\
{[85]}\end{array}$ \\
\hline
\end{tabular}


Table 1. Cont.

\begin{tabular}{|c|c|c|c|}
\hline Metabolites & Side of Origin & (Patho) Physiological Effects & Ref. \\
\hline \multicolumn{4}{|c|}{ Circulating Uremic Toxins } \\
\hline Indole-3-acetic acid & Colon & $\begin{array}{c}\text { Neutrophils: } \\
\uparrow \text { peroxidase activity } \\
\uparrow \text { Glucose and glutamine metabolism } \\
\uparrow \text { Oxygen consumption } \\
\uparrow \text { Structural changes and cell death } \\
\uparrow \text { Phagocytic activity } \\
\text { Genotoxicity }\end{array}$ & $\begin{array}{c}{[87]} \\
{[88]} \\
{[88]} \\
{[87,89]} \\
{[91]} \\
{[92]}\end{array}$ \\
\hline Trimethylamine-oxide & $\begin{array}{l}\text { Liver, kidney, } \\
\text { and other }\end{array}$ & $\begin{array}{c}\uparrow \text { VCAM-1 } \\
\uparrow \text { Monocyte-endothelial } \\
\text { adhesion } \rightarrow \text { inflammatory gene expression } \\
\text { Activates PKC and p-NF- } \mathrm{BB}\end{array}$ & [94] \\
\hline $\mathrm{H}_{2} \mathrm{~S}$ & $\begin{array}{l}\text { Brain, vascular } \\
\text { tissue, liver, } \\
\text { kidney, RBC, } \\
\text { and other }\end{array}$ & $\begin{array}{c}\text { Leukocytes: } \\
\downarrow \text { Leukocyte-endothelial adhesion } \\
\downarrow \text { Leukocyte infiltration } \\
\text { Regulation of post-translational } \\
\text { modification of NF- } \kappa \text { B pathway } \\
\text { Macrophages: } \\
\downarrow \text { Pro-inflammatory cytokine production } \\
\downarrow \text { COX-2 and NO production } \\
\downarrow \text { Macrophage motitlity } \\
\downarrow \text { MPO activity } \\
\downarrow \text { Inflammation } \\
\downarrow \text { Antigen-binding } \\
\downarrow \text { Cell lysis (glomerular mesangial cells and T-lymphocytes) }\end{array}$ & $\begin{array}{l}{[97,98]} \\
{[100]}\end{array}$ \\
\hline
\end{tabular}

LDH: lactate dehydrogenase; ATP: adenosine triphosphate; TE(E)R: transepithelial (electrical) resistance; IL: interleukin; REG3G: regenerating islet-derived 3 gamma;ND: none described; RBC: red blood cells: ROS: reactive oxygen species; DCs: dendritic cells; HUVEC: human vascular endothelial cells; VCAM: vascular cell adhesion molecule: PKC: protein kinase C; COX: cyclooxygenase; NO: nitric oxide.; MPO: myeloperoxidase. $\downarrow$ : decreased; $\uparrow:$ increased.

$\mathrm{H}_{2} \mathrm{~S}$ appears to play an important role in the modulation of the immune response by regulating the post-translational modification of the NF-kB pathway. However, depending on the model and the concentration used, $\mathrm{H}_{2} \mathrm{~S}$ functions as an activator and an inhibitor towards this pathway [100]. $\mathrm{H}_{2} \mathrm{~S}$ donors also inhibit macrophage pro-inflammatory cytokine production, as well as cyclooxygenase-2 and nitric oxide production, and decrease macrophage motility. CBS and CSE are regulated by ox-LDLs, while $\mathrm{H}_{2} \mathrm{~S}$ mitigates ox-LDL-induced cholesterol efflux and foam cell formation [44]. Endogenous levels of sulfide reversibly inhibit the activity of circulating and endothelium-bound myeloperoxidase (MPO), suggesting a mediatory role on the oxidant-producing function of the enzyme. Furthermore, the produced polysulfides, together with MPO-catalyzed sulfide oxidation and the lack of interaction between MPO and sulfide oxidation products, may envisage a modulatory role of MPO in sulfide signaling [101]. It has been demonstrated that $\mathrm{H}_{2} \mathrm{~S}$ is able to reduce inflammation in a mononuclear cell adhesion model by a mechanism related to ADAM17-dependent TNF- $\alpha$ activation [102]. Most studies on $\mathrm{H}_{2} \mathrm{~S}$ and immune function are related to cellular immunity. However, it has been shown that antibody cleavage of the disulfide bonds between heavy and light chains and the ensuing sulfhydration is induced by $\mathrm{H}_{2} \mathrm{~S}$ donors, which also suppresses the alternative complement activation pathway. $\mathrm{H}_{2} \mathrm{~S}$-treated antibodies exhibit a marked reduction in antigen-binding ability, and $\mathrm{H}_{2} \mathrm{~S}$ inhibits cell lysis in glomerular mesangial cells and in human T lymphocytes [103].

Little is known about this topic in CKD and dialysis patients. In uremia, CSE activity is reduced in blood mononuclear cells from uremic patients on hemodialysis [104]. CSE downregulation could be due to a uremic toxin, perhaps lanthionine, which is able to reduce $\mathrm{H}_{2} \mathrm{~S}$ production in hepatoma cells. It is currently unknown if the gut microbiome is able to influence immune function in CKD patients through sulfur compounds and in particular through $\mathrm{H}_{2} \mathrm{~S}$. 


\section{Conclusions}

Several uremic metabolites and their precursors exert immunomodulatory effects both at their side of origin and especially in the circulation. At the side of the intestine p-cresol, TMA and $\mathrm{H}_{2} \mathrm{~S}$ can affect the intestinal barrier structure and function and could in this way stimulate cells of the immune system and contribute to inflammation. In contrast, the bacterial metabolization products of tryptophan, indole and IAA, seem to be beneficial for the intestinal epithelial cells and the intestinal mucosa. Aiming at a decreased generation of especially p-cresol, by e.g., changing dietary intake [105] or by the administration of pre- [106], pro- [107] or synbiotics [108], could contribute to the intactness of the intestinal barrier function, avoiding pro-inflammatory reactions. However, in view of the local intestinal beneficial effects of end products of the bacterial tryptophan metabolism, intestinal absorption, by affecting transporter protein expression and/or function, rather than generation, should be explored and targeted. Both strategies will contribute to decreased levels of circulating protein-bound uremic toxins and might reduce micro-inflammation in CKD. To date, little is known about the role of gut sulfur compounds and $\mathrm{H}_{2} \mathrm{~S}$, in particular in the context of CKD, where a profound dysregulation of their metabolism is present.

Author Contributions: Writing—original draft preparation, G.G. and A.P.; writing—review and editing, G.G., T.G., A.P.; visualization, G.G. and T.G.; supervision, G.G. All authors have read and agreed to the published version of the manuscript.

Funding: G.G. and A.P. are beneficiaries of a project (STRATEGY-CKD) that has received funding from the European Union's Horizon 2020 research and innovation program under grant agreement No [860329]. T.G. is supported by The Research Foundation Flanders (FWO Vlaanderen) grant No. G017815N. G.G. and A.P. are members of the European uremic toxin workgroup (EUTox).

Conflicts of Interest: The authors declare no conflict of interest.

\section{References}

1. Medzhitov, R. Origin and physiological roles of inflammation. Nature 2008, 454, 428-435. [CrossRef] [PubMed]

2. Zewinger, S.; Schumann, T.; Fliser, D.; Speer, T. Innate immunity in CKD-associated vascular diseases. Nephrol. Dial. Transplant. 2016, 31, 1813-1821. [CrossRef] [PubMed]

3. Vaziri, N.D.; Zhao, Y.Y.; Pahl, M.V. Altered intestinal microbial flora and impaired epithelial barrier structure and function in CKD: The nature, mechanisms, consequences and potential treatment. Nephrol. Dial. Transplant. 2016, 31, 737-746. [CrossRef] [PubMed]

4. Aronov, P.A.; Luo, F.J.; Plummer, N.S.; Quan, Z.; Holmes, S.; Hostetter, T.H.; Meyer, T.W. Colonic contribution to uremic solutes. J. Am. Soc. Nephrol. JASN 2011, 22, 1769-1776. [CrossRef] [PubMed]

5. Mair, R.D.; Sirich, T.L.; Plummer, N.S.; Meyer, T.W. Characteristics of Colon-Derived Uremic Solutes. Clin. J. Am. Soc. Nephrol. CJASN 2018, 13, 1398-1404. [CrossRef]

6. Dou, L.; Sallee, M.; Cerini, C.; Poitevin, S.; Gondouin, B.; Jourde-Chiche, N.; Fallague, K.; Brunet, P.; Calaf, R.; Dussol, B.; et al. The cardiovascular effect of the uremic solute indole-3 acetic acid. J. Am. Soc. Nephrol. JASN 2015, 26, 876-887. [CrossRef]

7. Liabeuf, S.; Barreto, D.V.; Barreto, F.C.; Meert, N.; Glorieux, G.; Schepers, E.; Temmar, M.; Choukroun, G.; Vanholder, R.; Massy, Z.A. Free p-cresylsulphate is a predictor of mortality in patients at different stages of chronic kidney disease. Nephrol. Dial. Transplant. 2010, 25, 1183-1191. [CrossRef]

8. Liabeuf, S.; Glorieux, G.; Lenglet, A.; Diouf, M.; Schepers, E.; Desjardins, L.; Choukroun, G.; Vanholder, R.; Massy, Z.A. Does p-cresylglucuronide have the same impact on mortality as other protein-bound uremic toxins? PLoS ONE 2013, 8, e67168. [CrossRef]

9. Tang, W.H.; Kitai, T.; Hazen, S.L. Gut Microbiota in Cardiovascular Health and Disease. Circ. Res. 2017, 120, 1183-1196. [CrossRef]

10. Vanholder, R.; Pletinck, A.; Schepers, E.; Glorieux, G. Biochemical and Clinical Impact of Organic Uremic Retention Solutes: A Comprehensive Update. Toxins 2018, 10, 33. [CrossRef] 
11. Perna, A.F.; Glorieux, G.; Zacchia, M.; Trepiccione, F.; Capolongo, G.; Vigorito, C.; Anishchenko, E.; Ingrosso, D. The role of the intestinal microbiota in uremic solute accumulation: A focus on sulfur compounds. J. Nephrol. 2019, 32, 733-740. [CrossRef] [PubMed]

12. Ley, R.E.; Peterson, D.A.; Gordon, J.I. Ecological and evolutionary forces shaping microbial diversity in the human intestine. Cell 2006, 124, 837-848. [CrossRef] [PubMed]

13. Yang, T.; Richards, E.M.; Pepine, C.J.; Raizada, M.K. The gut microbiota and the brain-gut-kidney axis in hypertension and chronic kidney disease. Nat. Rev. Nephrol. 2018, 14, 442-456. [CrossRef] [PubMed]

14. Maynard, C.L.; Elson, C.O.; Hatton, R.D.; Weaver, C.T. Reciprocal interactions of the intestinal microbiota and immune system. Nature 2012, 489, 231-241. [CrossRef]

15. Hooper, L.V.; Littman, D.R.; Macpherson, A.J. Interactions between the microbiota and the immune system. Science 2012, 336, 1268-1273. [CrossRef]

16. McDermott, A.J.; Huffnagle, G.B. The microbiome and regulation of mucosal immunity. Immunology 2014, 142, 24-31. [CrossRef]

17. Hida, M.; Aiba, Y.; Sawamura, S.; Suzuki, N.; Satoh, T.; Koga, Y. Inhibition of the accumulation of uremic toxins in the blood and their precursors in the feces after oral administration of Lebenin, a lactic acid bacteria preparation, to uremic patients undergoing hemodialysis. Nephron 1996, 74, 349-355. [CrossRef]

18. Simenhoff, M.L.; Saukkonen, J.J.; Burke, J.F.; Wesson, L.G., Jr.; Schaedler, R.W.; Gordon, S.J. Bacterial populations of the small intestine in uremia. Nephron 1978, 22, 63-68. [CrossRef]

19. Strid, H.; Simren, M.; Stotzer, P.O.; Ringstrom, G.; Abrahamsson, H.; Bjornsson, E.S. Patients with chronic renal failure have abnormal small intestinal motility and a high prevalence of small intestinal bacterial overgrowth. Digestion 2003, 67, 129-137. [CrossRef]

20. Gryp, T.; Huys, G.R.B.; Joossens, M.; Van Biesen, W.; Glorieux, G.; Vaneechoutte, M. Isolation and Quantification of Uremic Toxin Precursor-Generating Gut Bacteria in Chronic Kidney Disease Patients. Int. J. Mol. Sci. 2020, 21, 1986. [CrossRef]

21. Wang, X.; Yang, S.; Li, S.; Zhao, L.; Hao, Y.; Qin, J.; Zhang, L.; Zhang, C.; Bian, W.; Zuo, L.I.; et al. Aberrant gut microbiota alters host metabolome and impacts renal failure in humans and rodents. Gut 2020. [CrossRef] [PubMed]

22. Bode, J.G.; Ehlting, C.; Haussinger, D. The macrophage response towards LPS and its control through the p38(MAPK)-STAT3 axis. Cell Signal. 2012, 24, 1185-1194. [CrossRef] [PubMed]

23. Feroze, U.; Kalantar-Zadeh, K.; Sterling, K.A.; Molnar, M.Z.; Noori, N.; Benner, D.; Shah, V.; Dwivedi, R.; Becker, K.; Kovesdy, C.P.; et al. Examining associations of circulating endotoxin with nutritional status, inflammation, and mortality in hemodialysis patients. J. Ren. Nutr. 2012, 22, 317-326. [CrossRef] [PubMed]

24. McIntyre, C.W.; Harrison, L.E.; Eldehni, M.T.; Jefferies, H.J.; Szeto, C.C.; John, S.G.; Sigrist, M.K.; Burton, J.O.; Hothi, D.; Korsheed, S.; et al. Circulating endotoxemia: A novel factor in systemic inflammation and cardiovascular disease in chronic kidney disease. Clin. J. Am. Soc. Nephrol. CJASN 2011, 6, 133-141. [CrossRef]

25. Raj, D.S.; Carrero, J.J.; Shah, V.O.; Qureshi, A.R.; Barany, P.; Heimburger, O.; Lindholm, B.; Ferguson, J.; Moseley, P.L.; Stenvinkel, P. Soluble CD14 levels, interleukin 6, and mortality among prevalent hemodialysis patients. Am. J. Kidney Dis. 2009, 54, 1072-1080. [CrossRef]

26. Vince, A.; Dawson, A.M.; Park, N.; O'Grady, F. Ammonia production by intestinal bacteria. Gut 1973, 14, 171-177. [CrossRef]

27. Wu, M.J.; Chang, C.S.; Cheng, C.H.; Chen, C.H.; Lee, W.C.; Hsu, Y.H.; Shu, K.H.; Tang, M.J. Colonic transit time in long-term dialysis patients. Am. J. Kidney Dis. 2004, 44, 322-327. [CrossRef]

28. Gryp, T.; De Paepe, K.; Vanholder, R.; Kerckhof, F.M.; Van Biesen, W.; Van de Wiele, T.; Verbeke, F.; Speeckaert, M.; Joossens, M.; Couttenye, M.M.; et al. Gut microbiota generation of protein-bound uremic toxins and related metabolites is not altered at different stages of chronic kidney disease. Kidney Int. 2020. [CrossRef]

29. Mishima, E.; Fukuda, S.; Mukawa, C.; Yuri, A.; Kanemitsu, Y.; Matsumoto, Y.; Akiyama, Y.; Fukuda, N.N.; Tsukamoto, H.; Asaji, K.; et al. Evaluation of the impact of gut microbiota on uremic solute accumulation by a CE-TOFMS-based metabolomics approach. Kidney Int. 2017, 92, 634-645. [CrossRef]

30. Poesen, R.; Windey, K.; Neven, E.; Kuypers, D.; De Preter, V.; Augustijns, P.; D’Haese, P.; Evenepoel, P.; Verbeke, K.; Meijers, B. The Influence of CKD on Colonic Microbial Metabolism. J. Am. Soc. Nephrol. JASN 2016, 27, 1389-1399. [CrossRef] 
31. Kawakami, K.; Kojima, K.; Makino, I.; Kato, I.; Onoue, M. Fasting enhances p-Cresol production in the rat intestinal tract. Exp. Anim. 2007, 56, 301-307. [CrossRef] [PubMed]

32. Wong, X.; Carrasco-Pozo, C.; Escobar, E.; Navarrete, P.; Blachier, F.; Andriamihaja, M.; Lan, A.; Tome, D.; Cires, M.J.; Pastene, E.; et al. Deleterious Effect of p-Cresol on Human Colonic Epithelial Cells Prevented by Proanthocyanidin-Containing Polyphenol Extracts from Fruits and Proanthocyanidin Bacterial Metabolites. J. Agric. Food Chem. 2016, 64, 3574-3583. [CrossRef] [PubMed]

33. Al Hinai, E.A.; Kullamethee, P.; Rowland, I.R.; Swann, J.; Walton, G.E.; Commane, D.M. Modelling the role of microbial p-cresol in colorectal genotoxicity. Gut Microbes 2019, 10, 398-411. [CrossRef] [PubMed]

34. Kawakami, K.; Makino, I.; Kato, I.; Uchida, K.; Onoue, M. p-Cresol inhibits IL-12 production by murine macrophages stimulated with bacterial immunostimulant. Immunopharmacol. Immunotoxicol. 2009, 31, 304-309. [CrossRef]

35. Vanholder, R.; De Smet, R.; Waterloos, M.A.; Van Landschoot, N.; Vogeleere, P.; Hoste, E.; Ringoir, S. Mechanisms of uremic inhibition of phagocyte reactive species production: Characterization of the role of p-cresol. Kidney Int. 1995, 47, 510-517. [CrossRef]

36. Venkatesh, M.; Mukherjee, S.; Wang, H.; Li, H.; Sun, K.; Benechet, A.P.; Qiu, Z.; Maher, L.; Redinbo, M.R.; Phillips, R.S.; et al. Symbiotic bacterial metabolites regulate gastrointestinal barrier function via the xenobiotic sensor PXR and Toll-like receptor 4. Immunity 2014, 41, 296-310. [CrossRef]

37. Zelante, T.; Iannitti, R.G.; Cunha, C.; De Luca, A.; Giovannini, G.; Pieraccini, G.; Zecchi, R.; D’Angelo, C.; Massi-Benedetti, C.; Fallarino, F.; et al. Tryptophan catabolites from microbiota engage aryl hydrocarbon receptor and balance mucosal reactivity via interleukin-22. Immunity 2013, 39, 372-385. [CrossRef]

38. Lee, J.H.; Lee, J. Indole as an intercellular signal in microbial communities. FEMS Microbiol. Rev. 2010, 34, 426-444. [CrossRef]

39. Bansal, T.; Alaniz, R.C.; Wood, T.K.; Jayaraman, A. The bacterial signal indole increases epithelial-cell tight-junction resistance and attenuates indicators of inflammation. Proc. Natl. Acad. Sci.USA 2010, 107, 228-233. [CrossRef]

40. Hendrikx, T.; Duan, Y.; Wang, Y.; Oh, J.H.; Alexander, L.M.; Huang, W.; Starkel, P.; Ho, S.B.; Gao, B.; Fiehn, O.; et al. Bacteria engineered to produce IL-22 in intestine induce expression of REG3G to reduce ethanol-induced liver disease in mice. Gut 2019, 68, 1504-1515. [CrossRef]

41. Brieger, H.; Hodes, W.A. Toxic effects of exposure to vapors of aliphatic amines. AMA Arch. Ind. Hyg. Occup. Med. 1951, 3, 287-291. [PubMed]

42. Fluhr, J.W.; Kelterer, D.; Fuchs, S.; Kaatz, M.; Grieshaber, R.; Kleesz, P.; Elsner, P. Additive impairment of the barrier function and irritation by biogenic amines and sodium lauryl sulphate: A controlled in vivo tandem irritation study. Skin Pharm. Physiol. 2005, 18, 88-97. [CrossRef] [PubMed]

43. Yang, J.; Minkler, P.; Grove, D.; Wang, R.; Willard, B.; Dweik, R.; Hine, C. Non-enzymatic hydrogen sulfide production from cysteine in blood is catalyzed by iron and vitamin B6. Commun. Biol. 2019, 2, 194. [CrossRef] [PubMed]

44. Murphy, B.; Bhattacharya, R.; Mukherjee, P. Hydrogen sulfide signaling in mitochondria and disease. FASEB J. Off. Publ. Fed. Am. Soc. Exp. Biol. 2019, 33, 13098-13125. [CrossRef]

45. Koike, S.; Nishimoto, S.; Ogasawara, Y. Cysteine persulfides and polysulfides produced by exchange reactions with $\mathrm{H} 2 \mathrm{~S}$ protect $\mathrm{SH}-\mathrm{SY} 5 Y$ cells from methylglyoxal-induced toxicity through Nrf2 activation. Redox Biol. 2017, 12, 530-539. [CrossRef]

46. Koike, S.; Ogasawara, Y. Sulfur Atom in its Bound State Is a Unique Element Involved in Physiological Functions in Mammals. Molecules 2016, 21, 1753. [CrossRef]

47. Libiad, M.; Vitvitsky, V.; Bostelaar, T.; Bak, D.W.; Lee, H.J.; Sakamoto, N.; Fearon, E.; Lyssiotis, C.A.; Weerapana, E.; Banerjee, R. Hydrogen sulfide perturbs mitochondrial bioenergetics and triggers metabolic reprogramming in colon cells. J. Biol. Chem. 2019, 294, 12077-12090. [CrossRef]

48. Shen, X.; Pattillo, C.B.; Pardue, S.; Bir, S.C.; Wang, R.; Kevil, C.G. Measurement of plasma hydrogen sulfide in vivo and in vitro. Free Radic. Biol. Med. 2011, 50, 1021-1031. [CrossRef]

49. Tomasova, L.; Konopelski, P.; Ufnal, M. Gut Bacteria and Hydrogen Sulfide: The New Old Players in Circulatory System Homeostasis. Molecules 2016, 21, 1558. [CrossRef] 
50. Barton, L.L.; Ritz, N.L.; Fauque, G.D.; Lin, H.C. Sulfur Cycling and the Intestinal Microbiome. Dig. Dis. Sci. 2017, 62, 2241-2257. [CrossRef]

51. Magee, E.A.; Richardson, C.J.; Hughes, R.; Cummings, J.H. Contribution of dietary protein to sulfide production in the large intestine: An in vitro and a controlled feeding study in humans. Am. J. Clin. Nutr. 2000, 72, 1488-1494. [CrossRef] [PubMed]

52. Maseda, C.; Hayakawa, A.; Okuda, K.; Asari, M.; Tanaka, H.; Yamada, H.; Jin, S.; Horioka, K.; Matoba, K.; Shiono, H.; et al. Liquid chromatography-tandem mass spectrometry method for the determination of thiosulfate in human blood and urine as an indicator of hydrogen sulfide poisoning. Leg. Med. (Tokyo, Japan) 2017, 24, 67-74. [CrossRef] [PubMed]

53. Shatalin, K.; Shatalina, E.; Mironov, A.; Nudler, E. H2S: A universal defense against antibiotics in bacteria. Science 2011, 334, 986-990. [CrossRef] [PubMed]

54. Mironov, A.; Seregina, T.; Nagornykh, M.; Luhachack, L.G.; Korolkova, N.; Lopes, L.E.; Kotova, V.; Zavilgelsky, G.; Shakulov, R.; Shatalin, K.; et al. Mechanism of H2S-mediated protection against oxidative stress in Escherichia coli. Proc. Natl. Acad. Sci. USA 2017, 114, 6022-6027. [CrossRef] [PubMed]

55. Toliver-Kinsky, T.; Cui, W.; Toro, G.; Lee, S.J.; Shatalin, K.; Nudler, E.; Szabo, C. H2S, a Bacterial Defense Mechanism against the Host Immune Response. Infect. Immun. 2019, 87, e00272-18. [CrossRef]

56. Roediger, W.E.; Duncan, A.; Kapaniris, O.; Millard, S. Reducing sulfur compounds of the colon impair colonocyte nutrition: Implications for ulcerative colitis. Gastroenterology 1993, 104, 802-809. [CrossRef]

57. Shen, X.; Carlstrom, M.; Borniquel, S.; Jadert, C.; Kevil, C.G.; Lundberg, J.O. Microbial regulation of host hydrogen sulfide bioavailability and metabolism. Free Radic. Biol. Med. 2013, 60, 195-200. [CrossRef]

58. Perna, A.F.; Di Nunzio, A.; Amoresano, A.; Pane, F.; Fontanarosa, C.; Pucci, P.; Vigorito, C.; Cirillo, G.; Zacchia, M.; Trepiccione, F.; et al. Divergent behavior of hydrogen sulfide pools and of the sulfur metabolite lanthionine, a novel uremic toxin, in dialysis patients. Biochimie 2016, 126, 97-107. [CrossRef]

59. Jankowski, J.; Westhof, T.; Vaziri, N.D.; Ingrosso, D.; Perna, A.F. Gases as uremic toxins: Is there something in the air? Semin. Nephrol. 2014, 34, 135-150. [CrossRef]

60. Perna, A.F.; Anishchenko, E.; Vigorito, C.; Zacchia, M.; Trepiccione, F.; D'Aniello, S.; Ingrosso, D. Zebrafish, a Novel Model System to Study Uremic Toxins: The Case for the Sulfur Amino Acid Lanthionine. Int. J. Mol. Sci. 2018, 19, 1323. [CrossRef]

61. Perna, A.F.; Zacchia, M.; Trepiccione, F.; Ingrosso, D. The Sulfur Metabolite Lanthionine: Evidence for a Role as a Novel Uremic Toxin. Toxins 2017, 9, 26. [CrossRef] [PubMed]

62. Vigorito, C.; Anishchenko, E.; Mele, L.; Capolongo, G.; Trepiccione, F.; Zacchia, M.; Lombari, P.; Capasso, R.; Ingrosso, D.; Perna, A.F. Uremic Toxin Lanthionine Interferes with the Transsulfuration Pathway, Angiogenetic Signaling and Increases Intracellular Calcium. Int. J. Mol. Sci. 2019, 20, 2269. [CrossRef] [PubMed]

63. Ramakrishna, B.S.; Gee, D.; Weiss, A.; Pannall, P.; Roberts-Thomson, I.C.; Roediger, W.E. Estimation of phenolic conjugation by colonic mucosa. J. Clin. Pathol. 1989, 42, 620-623. [CrossRef] [PubMed]

64. Schepers, E.; Glorieux, G.; Vanholder, R. The gut: The forgotten organ in uremia? Blood Purif. 2010, 29, 130-136. [CrossRef]

65. De Loor, H.; Bammens, B.; Evenepoel, P.; De Preter, V.; Verbeke, K. Gas chromatographic-mass spectrometric analysis for measurement of p-cresol and its conjugated metabolites in uremic and normal serum. Clin. Chem. 2005, 51, 1535-1538. [CrossRef]

66. Poesen, R.; Evenepoel, P.; de Loor, H.; Kuypers, D.; Augustijns, P.; Meijers, B. Metabolism, Protein Binding, and Renal Clearance of Microbiota-Derived p-Cresol in Patients with CKD. Clin. J. Am. Soc. Nephrol. CJASN 2016, 11, 1136-1144. [CrossRef]

67. Meyer, T.W.; Hostetter, T.H. Uremic solutes from colon microbes. Kidney Int. 2012, 81, 949-954. [CrossRef]

68. Schepers, E.; Meert, N.; Glorieux, G.; Goeman, J.; Van der Eycken, J.; Vanholder, R. P-cresylsulphate, the main in vivo metabolite of p-cresol, activates leucocyte free radical production. Nephrol. Dial. Transplant. 2007, 22, 592-596. [CrossRef]

69. Meert, N.; Schepers, E.; Glorieux, G.; Van Landschoot, M.; Goeman, J.L.; Waterloos, M.A.; Dhondt, A.; Van der Eycken, J.; Vanholder, R. Novel method for simultaneous determination of p-cresylsulphate and p-cresylglucuronide: Clinical data and pathophysiological implications. Nephrol. Dial. Transplant. 2012, 27, 2388-2396. [CrossRef] 
70. Pletinck, A.; Glorieux, G.; Schepers, E.; Cohen, G.; Gondouin, B.; Van Landschoot, M.; Eloot, S.; Rops, A.; Van de Voorde, J.; De Vriese, A.; et al. Protein-bound uremic toxins stimulate crosstalk between leukocytes and vessel wall. J. Am. Soc. Nephrol. JASN 2013, 24, 1981-1994. [CrossRef]

71. Han, H.; Chen, Y.; Zhu, J.; Ni, J.; Sun, J.; Zhang, R. Atorvastatin attenuates pcresyl sulfateinduced atherogenesis and plaque instability in ApoE knockout mice. Mol. Med. Rep. 2016, 14, 3122-3128. [CrossRef] [PubMed]

72. Viaene, L.; Evenepoel, P.; Meijers, B.; Vanderschueren, D.; Overbergh, L.; Mathieu, C. Uremia suppresses immune signal-induced CYP27B1 expression in human monocytes. Am. J. Nephrol 2012, 36, 497-508. [CrossRef] [PubMed]

73. Shiba, T.; Kawakami, K.; Sasaki, T.; Makino, I.; Kato, I.; Kobayashi, T.; Uchida, K.; Kaneko, K. Effects of intestinal bacteria-derived p-cresyl sulfate on Th1-type immune response in vivo and in vitro. Toxicol. Appl. Pharmacol. 2014, 274, 191-199. [CrossRef] [PubMed]

74. Shiba, T.; Makino, I.; Kawakami, K.; Kato, I.; Kobayashi, T.; Kaneko, K. p-Cresyl sulfate suppresses lipopolysaccharide-induced anti-bacterial immune responses in murine macrophages in vitro. Toxicol. Lett. 2016, 245, 24-30. [CrossRef] [PubMed]

75. Shiba, T.; Makino, I.; Sasaki, T.; Fukuhara, Y.; Kawakami, K.; Kato, I.; Kobayashi, T. p-Cresyl sulfate decreases peripheral B cells in mice with adenine-induced renal dysfunction. Toxicol. Appl. Pharm. 2018, 342, 50-59. [CrossRef] [PubMed]

76. Azevedo, M.L.; Bonan, N.B.; Dias, G.; Brehm, F.; Steiner, T.M.; Souza, W.M.; Stinghen, A.E.; Barreto, F.C.; Elifio-Esposito, S.; Pecoits-Filho, R.; et al. p-Cresyl sulfate affects the oxidative burst, phagocytosis process, and antigen presentation of monocyte-derived macrophages. Toxicol. Lett. 2016, 263, 1-5. [CrossRef]

77. Chiu, Y.L.; Shu, K.H.; Yang, F.J.; Chou, T.Y.; Chen, P.M.; Lay, F.Y.; Pan, S.Y.; Lin, C.J.; Litjens, N.H.R.; Betjes, M.G.H.; et al. A comprehensive characterization of aggravated aging-related changes in T lymphocytes and monocytes in end-stage renal disease: The iESRD study. Immun. Ageing 2018, 15, 27. [CrossRef]

78. Borges Bonan, N.; Schepers, E.; Pecoits-Filho, R.; Dhondt, A.; Pletinck, A.; De Somer, F.; Vanholder, R.; Van Biesen, W.; Moreno-Amaral, A.; Glorieux, G. Contribution of the uremic milieu to an increased pro-inflammatory monocytic phenotype in chronic kidney disease. Sci. Rep. 2019, 9, 10236. [CrossRef]

79. Hwang, W.B.; Kim, D.J.; Oh, G.S.; Park, J.H. Aryl Hydrocarbon Receptor Ligands Indoxyl 3-sulfate and Indole-3-carbinol Inhibit FMS-like Tyrosine Kinase 3 Ligand-induced Bone Marrow-derived plasmacytoid Dendritic Cell Differentiation. Immune Netw. 2018, 18, e35. [CrossRef]

80. Ghimire, S.; Matos, C.; Caioni, M.; Weber, D.; Peter, K.; Holler, E.; Kreutz, M.; Renner, K. Indoxyl 3-sulfate inhibits maturation and activation of human monocyte-derived dendritic cells. Immunobiology 2018, 223, 239-245. [CrossRef]

81. Kim, H.Y.; Yoo, T.H.; Hwang, Y.; Lee, G.H.; Kim, B.; Jang, J.; Yu, H.T.; Kim, M.C.; Cho, J.Y.; Lee, C.J.; et al. Indoxyl sulfate (IS)-mediated immune dysfunction provokes endothelial damage in patients with end-stage renal disease (ESRD). Sci. Rep. 2017, 7, 3057. [CrossRef] [PubMed]

82. Ito, S.; Higuchi, Y.; Yagi, Y.; Nishijima, F.; Yamato, H.; Ishii, H.; Osaka, M.; Yoshida, M. Reduction of indoxyl sulfate by AST-120 attenuates monocyte inflammation related to chronic kidney disease. J. Leukoc. Biol. 2013, 93, 837-845. [CrossRef] [PubMed]

83. Kim, H.Y.; Yoo, T.H.; Cho, J.Y.; Kim, H.C.; Lee, W.W. Indoxyl sulfate-induced TNF-alpha is regulated by crosstalk between the aryl hydrocarbon receptor, NF-kappaB, and SOCS2 in human macrophages. FASEB J. Off. Publ. Fed. Am. Soc. Exp. Biol. 2019, 33, 10844-10858. [CrossRef]

84. Adesso, S.; Popolo, A.; Bianco, G.; Sorrentino, R.; Pinto, A.; Autore, G.; Marzocco, S. The uremic toxin indoxyl sulphate enhances macrophage response to LPS. PLoS ONE 2013, 8, e76778. [CrossRef] [PubMed]

85. Stockler-Pinto, M.B.; Soulage, C.O.; Borges, N.A.; Cardozo, L.; Dolenga, C.J.; Nakao, L.S.; Pecoits-Filho, R.; Fouque, D.; Mafra, D. From bench to the hemodialysis clinic: Protein-bound uremic toxins modulate NF-kappaB/Nrf2 expression. Int. Urol. Nephrol. 2018, 50, 347-354. [CrossRef] [PubMed]

86. Ito, S.; Osaka, M.; Higuchi, Y.; Nishijima, F.; Ishii, H.; Yoshida, M. Indoxyl sulfate induces leukocyte-endothelial interactions through up-regulation of E-selectin. J. Biol. Chem. 2010, 285, 38869-38875. [CrossRef]

87. Pires de Melo, M.; Curi, T.C.; Miyasaka, C.K.; Palanch, A.C.; Curi, R. Effect of indole acetic acid on oxygen metabolism in cultured rat neutrophil. Gen. Pharm. 1998, 31, 573-578. [CrossRef] 
88. De Melo, M.P.; Pithon-Curi, T.C.; Curi, R. Indole-3-acetic acid increases glutamine utilization by high peroxidase activity-presenting leukocytes. Life Sci. 2004, 75, 1713-1725. [CrossRef]

89. De Melo, M.P.; Curi, T.C.; Curi, R.; Di Mascio, P.; Cilento, G. Peroxidase activity may play a role in the cytotoxic effect of indole acetic acid. Photochem. Photobiol. 1997, 65, 338-341. [CrossRef]

90. De Melo, M.P.; de Lima, T.M.; Pithon-Curi, T.C.; Curi, R. The mechanism of indole acetic acid cytotoxicity. Toxicol. Lett. 2004, 148, 103-111. [CrossRef]

91. Lins, P.G.; Valle, C.R.; Pugine, S.M.; Oliveira, D.L.; Ferreira, M.S.; Costa, E.J.; De Melo, M.P. Effect of indole acetic acid administration on the neutrophil functions and oxidative stress from neutrophil, mesenteric lymph node and liver. Life Sci. 2006, 78, 564-570. [CrossRef] [PubMed]

92. Salopek-Sondi, B.; Piljac-Zegarac, J.; Magnus, V.; Kopjar, N. Free radical-scavenging activity and DNA damaging potential of auxins IAA and 2-methyl-IAA evaluated in human neutrophils by the alkaline comet assay. J. Biochem. Mol. Toxicol. 2010, 24, 165-173. [CrossRef] [PubMed]

93. Cashman, J.R.; Zhang, J. Human flavin-containing monooxygenases. Ann. Rev. Pharm. Toxicol. 2006, 46, 65-100. [CrossRef] [PubMed]

94. Seldin, M.M.; Meng, Y.; Qi, H.; Zhu, W.; Wang, Z.; Hazen, S.L.; Lusis, A.J.; Shih, D.M. Trimethylamine N-Oxide Promotes Vascular Inflammation Through Signaling of Mitogen-Activated Protein Kinase and Nuclear Factor-kappaB. J. Am. Heart Assoc. 2016, 5, e002767. [CrossRef]

95. Ma, G.; Pan, B.; Chen, Y.; Guo, C.; Zhao, M.; Zheng, L.; Chen, B. Trimethylamine N-oxide in atherogenesis: Impairing endothelial self-repair capacity and enhancing monocyte adhesion. Biosci. Rep. 2017, 37, BSR20160244. [CrossRef]

96. Haghikia, A.; Li, X.S.; Liman, T.G.; Bledau, N.; Schmidt, D.; Zimmermann, F.; Krankel, N.; Widera, C.; Sonnenschein, K.; Haghikia, A.; et al. Gut Microbiota-Dependent Trimethylamine N-Oxide Predicts Risk of Cardiovascular Events in Patients with Stroke and Is Related to Proinflammatory Monocytes. Arter. Thromb. Vasc. Biol. 2018, 38, 2225-2235. [CrossRef]

97. Li, L.; Bhatia, M.; Zhu, Y.Z.; Zhu, Y.C.; Ramnath, R.D.; Wang, Z.J.; Anuar, F.B.; Whiteman, M.; Salto-Tellez, M.; Moore, P.K. Hydrogen sulfide is a novel mediator of lipopolysaccharide-induced inflammation in the mouse. FASEB J. Off. Publ. Fed. Am. Soc. Exp. Biol. 2005, 19, 1196-1198. [CrossRef]

98. Zanardo, R.C.; Brancaleone, V.; Distrutti, E.; Fiorucci, S.; Cirino, G.; Wallace, J.L. Hydrogen sulfide is an endogenous modulator of leukocyte-mediated inflammation. FASEB J. Off. Publ. Fed. Am. Soc. Exp. Biol. 2006, 20, 2118-2120. [CrossRef]

99. Szabo, C. A timeline of hydrogen sulfide (H2S) research: From environmental toxin to biological mediator. Biochem. Pharm. 2018, 149, 5-19. [CrossRef]

100. Rodrigues, C.; Percival, S.S. Immunomodulatory Effects of Glutathione, Garlic Derivatives, and Hydrogen Sulfide. Nutrients 2019, 11, 295. [CrossRef]

101. Palinkas, Z.; Furtmuller, P.G.; Nagy, A.; Jakopitsch, C.; Pirker, K.F.; Magierowski, M.; Jasnos, K.; Wallace, J.L.; Obinger, C.; Nagy, P. Interactions of hydrogen sulfide with myeloperoxidase. Br. J. Pharmacol. 2015, 172, 1516-1532. [CrossRef] [PubMed]

102. Perna, A.F.; Sepe, I.; Lanza, D.; Capasso, R.; Zappavigna, S.; Capasso, G.; Caraglia, M.; Ingrosso, D. Hydrogen sulfide reduces cell adhesion and relevant inflammatory triggering by preventing ADAM17-dependent TNF-alpha activation. J. Cell Biochem. 2013, 114, 1536-1548. [CrossRef] [PubMed]

103. Zhang, Z.; Fang, X.; Yang, X.; Mitsui, T.; Huang, Y.; Mao, Z.; Huang, Y.; Takeda, M.; Yao, J. Hydrogen sulfide donor NaHS alters antibody structure and function via sulfhydration. Int. Immunopharmacol. 2019, 73, 491-501. [CrossRef] [PubMed]

104. Perna, A.F.; Luciano, M.G.; Ingrosso, D.; Pulzella, P.; Sepe, I.; Lanza, D.; Violetti, E.; Capasso, R.; Lombardi, C.; De Santo, N.G. Hydrogen sulphide-generating pathways in haemodialysis patients: A study on relevant metabolites and transcriptional regulation of genes encoding for key enzymes. Nephrol. Dial. Transplant. 2009, 24, 3756-3763. [CrossRef] [PubMed]

105. Ling, W.H.; Hanninen, O. Shifting from a conventional diet to an uncooked vegan diet reversibly alters fecal hydrolytic activities in humans. J. Nutr. 1992, 122, 924-930. [CrossRef] [PubMed]

106. Meijers, B.K.; De Preter, V.; Verbeke, K.; Vanrenterghem, Y.; Evenepoel, P. p-Cresyl sulfate serum concentrations in haemodialysis patients are reduced by the prebiotic oligofructose-enriched inulin. Nephrol. Dial. Transplant. 2010, 25, 219-224. [CrossRef] 
107. De Preter, V.; Vanhoutte, T.; Huys, G.; Swings, J.; De Vuyst, L.; Rutgeerts, P.; Verbeke, K. Effects of Lactobacillus casei Shirota, Bifidobacterium breve, and oligofructose-enriched inulin on colonic nitrogen-protein metabolism in healthy humans. Am. J. Physiol. Gastrointest. Liver Physiol. 2007, 292, G358-G368. [CrossRef]

108. Rossi, M.; Johnson, D.W.; Morrison, M.; Pascoe, E.M.; Coombes, J.S.; Forbes, J.M.; Szeto, C.C.; McWhinney, B.C.; Ungerer, J.P.; Campbell, K.L. Synbiotics Easing Renal Failure by Improving Gut Microbiology (SYNERGY): A Randomized Trial. Clin. J. Am. Soc. Nephrol. CJASN 2016, 11, 223-231. [CrossRef]

(C) 2020 by the authors. Licensee MDPI, Basel, Switzerland. This article is an open access article distributed under the terms and conditions of the Creative Commons Attribution (CC BY) license (http://creativecommons.org/licenses/by/4.0/). 